\title{
Risk Management Implementation in Indonesian State Budget Fiscal Risk Disclosure
}

\author{
Audra Rizki Himawan1,a; Yanuar Pribadi2,a* \\ $\mathbf{1}$ audrarizkihimawan@gmail.com; ${ }^{2}$ yanuar.pribadi@pknstan.ac.id \\ a Polytechnic of State Finance STAN \\ * corresponding author
}

\section{ABSTRACT}

Article history

Received 2020-12-23

Revised 2021-02-04

Accepted 2021-02-08

Keywords

Risk Management

Fiscal Risk

State Budget
Fiscal risk management is part of the management of financial risk in the State Budget. Basically, these risks are interrelated although they are different things. State financial risk as an inherent risk of State Budget has a different process from fiscal risk management. This study aims to evaluate the management process and disclosure of fiscal risk in the State Budget using a case study-qualitative approach. The integration of the risk management system between the risk management unit and the fiscal risk management unit, and development of fiscal risk management framework could improve the process of managing and disclosing fiscal risk in the Budget Statement.

This is an open access article under the CC-BY-SA license.

\section{Introduction}

The government has a role in setting and implementing intervention on the economy. The rational basis for the intervention is the probability of market failures in the form of overproduced goods or underproduced goods and the need to redistribute wealth between community groups (Gruber, 2019). Overproduced goods happen when the number of goods and/or services in the market exceeds the amount that should be available for maximum social efficiency, the Government imposes taxes and/or limits the number of goods and/or services. Conversely, if the number of goods and/or services in the market are smaller than the amount that should be available in order to create social efficiency (underproduced goods), the government can implement alternative policies such as subsidies, assignments to produce goods and/or services, supply of goods and/or self-managed services by the government, and public financing of private provision.

The policy to intervene in the economy is carried out by the Government in a State Budget (APBN). It includes policies on state income, state expenditures, transfers to regions 
and village funds, surpluses or deficits, financing revenues and expenditures including government investment policies that are prepared based on basic macroeconomic assumptions. In the formulation of APBN policies, there is uncertainty arise from domestic and foreign economic dynamics, operational dynamics, and implementation of certain policies by the government. These dynamics can lead to potential pressure on the APBN in terms of realization of state revenues, expenditures, budget surpluses or deficits, financing, and contingent liabilities so that the government needs to anticipate them in order to reduce the deviation in APBN implementation with its planning.

With this awareness, as part of the planning and budgeting process, the Government manages fiscal risk and discloses it in the Financial Note since Fiscal Year 2008. Fiscal risk management is a vital process considering there is bounded rationality in the process of making fiscal policy. Based on the concept of bounded rationality, policy rationality is limited to the ability of decision-makers to capture information (Robbins \& Coulter, 2016). In other words, decisions are made based on information provided to decision-makers. In the context of fiscal policy formulation, the limitation faced by policymakers is knowing the future domestic and global dynamics that will affect the basic macroeconomic assumptions used in APBN planning. Risk assessment can provide a valuable framework for determining priorities, policies, and effective allocation of resources by the government. The process of managing and disclosing fiscal risk can help fiscal policymakers to formulate and implement policies to anticipate pressure on the APBN.

The ideal risk management system consists of processes in the form of risk analysis, risk management, and risk evaluation (Mullai, 2006). Disclosure of fiscal risk is very important because awareness of potential hidden risks will increase so that it is hoped that the fiscal authority will be able to respond well to possible threats to the national economy in the coming years (Makhlani, 2009). As organizational risk management that is directly related to government fiscal outcomes, the Ministry of Finance has risk indicators such as the ratio of debt to gross domestic product, revenue shortfall to measure tax revenue realization, and so on. Debt management in the form of hedging interest rate risk and choosing the optimal maturity structure are important for maintaining stability and enhancing the sustainability of fiscal policy (Lloyd-Ellis \& Zhu, 2001). However, the linkage between inherent risks from the financial performance side of the APBN is a different process from fiscal risk management. Therefore, it is necessary to evaluate the distribution of risk information on the performance of the APBN as input in the management and monitoring of government fiscal risks. This is part of the improvement of the management process and disclosure of fiscal risks in the State Budget Financial Note. 


\section{Risk and Risk Management}

Risk is the effect of uncertainty on a target which is a deviation from the plan or target. This deviation can be positive (upside risk) and/or negative (downside risk). Effects can link with and generate opportunities and threats. Consequences are the outcome of events that can be certain or uncertain, have positive or negative effects as well as indirectly on targets, can escalate from sequences or accumulations, and can be expressed qualitatively and quantitatively. Risk management is a coordinated activity in order to direct and control an organization related to risk. Risk management is the process of identifying loss exposures (potential losses) faced by the organization and selecting the most appropriate techniques to deal with these losses (Redja \& McNamara, 2017).

Risk management aims to create and protect value in order to improve performance, encourage innovation, and support target achievement. Risk management objectives can be divided into pre-loss objectives and post-loss objectives. Pre-loss objectives consist of three objectives before losses occur, namely: facing potential losses economically; reduce anxiety; and fulfill obligations based on applicable regulations. Post-loss objectives consist of five objectives after the loss has occurred, namely: saving the organization; continue operations; stabilizing income; continuing organizational growth; and minimize the impact of losses on parties (Redja \& McNamara, 2017).

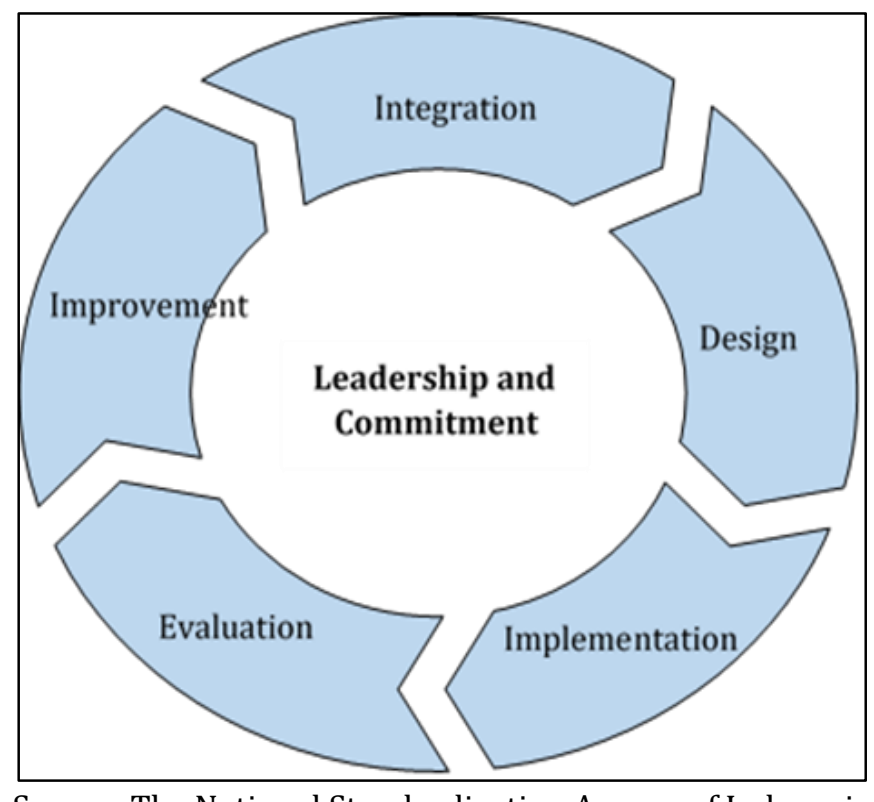

Source: The National Standardization Agency of Indonesia

Figure 1. Risk Management Framework

The risk management process is the systematic application of risk management policies, procedures, and practices. This iterative process integrates with management and decisionmaking processes and is integrated into the structure, operations, and processes of the 
organization. This process consists of interconnected activities. The risk management process consists of: communication and consultation; determination of scope, context, and criteria; risk assessment; risk treatment; monitoring and review; as well as recording and reporting.

The risk management process based on ISO also includes the process of determining risk appetite (Rittenberg \& Martens, 2012). Risk appetite is the amount of risk that can be accepted by the organization to create value. In addition to risk appetite, in controlling risk, it is necessary to pay attention to the differentiation of risk into inherent risk and residual risk (Sidabutar \& Kurniawan, 2018). Inherent risk is a calculated risk without internal control or other management action, while Residual risk is a risk that has considered internal control.

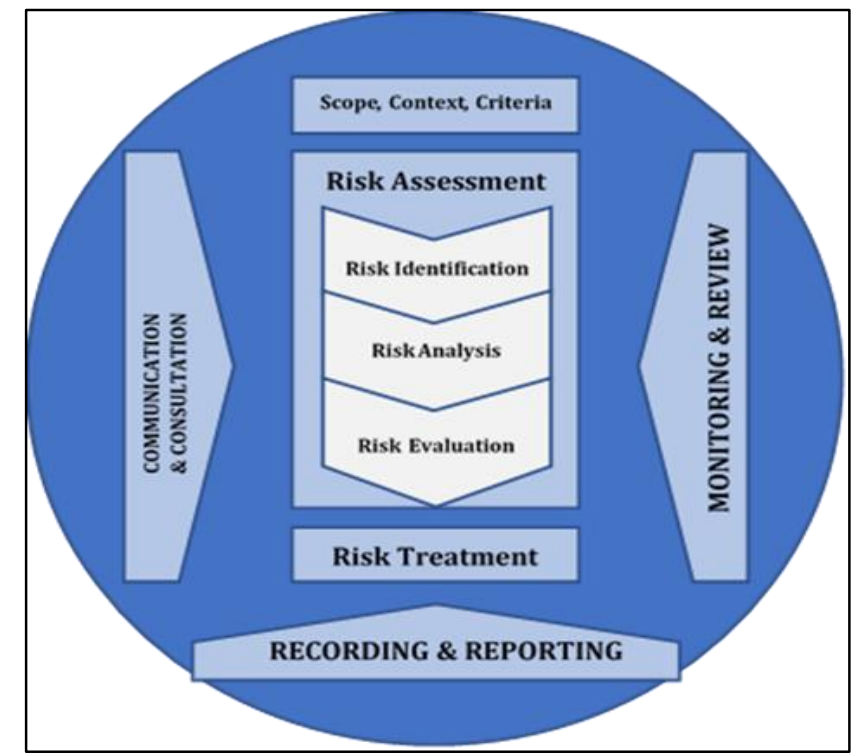

Source: The National Standardization Agency of Indonesia

Figure 2. Risk Management Processes

\section{Fiscal Risk}

Indonesia is a developing country that is developing an economy so that the fiscal sector is closely related to other economic sectors. Fiscal policies carried out by actors in the economic function of the government, including the central and regional governments, affect the economy, especially on aggregate demand (IMF, 2019). Components in the fiscal sector that are a combination of central, regional, and other public entities include income taxes, social contributions, grants, and others; expenditures recognized as expenses or as investments in non-financial assets; and financing the deficit. To analyze the reciprocal relationship of fiscal policy to the real, external, and monetary sectors in the economic context, the government can use the financial programming and policies framework (FPP) approach. 
Fiscal risk is a source of the financial pressure that can be faced by the government in the future (Brixi \& Schick, 2002). This risk focuses on the realization of the risk of an uncertain event associated with contingent liabilities. Political risk factors, including expropriation risk, play a significant role in raising sovereign spreads, as financial markets require an extra premium for political instability (Baldacci, Gupta, \& Mati, 2011). In addition, fiscal risk can also be defined as a deviation of fiscal outcomes against budget expectations or estimates that arise from macroeconomic shock and realization of contingent liabilities (Cebotari et al., 2009), or the potential difference between realization and expectations of fiscal outcomes due to differences between fiscal outcomes. Realization and macroeconomic assumptions as well as government operations that are outside the budget (Everaert, Fouad, Martin, \& Velloso, 2009).

The sources of fiscal risk are mapped into a fiscal risk matrix based on their characteristics, either direct or contingent as well as implicit or explicit (Brixi \& Schick, 2002). Direct liabilities in the matrix are liabilities that can be predicted when an event occurs. Contingent liabilities are liabilities arising from discrete and uncertain events. An explicit obligation is a specific government obligation that is defined in statutory regulations or agreements. Indirect obligations are obligations that are moral in nature or in the form of expected burdens, not legal sense, but based on public expectations or political pressure. Fiscal Risk Disclosure Norms and Standards

Fiscal transparency is information available to the public regarding the government's fiscal policy-making process (IMF, 2018). IMF details the definition of fiscal transparency into six aspects, consist of clarity, reliability, frequency, timeliness, relevance, and openness. Clarity means users can understand reporting easily. Reliability means that the report can be an accurate representation of the government's fiscal operations. Frequency means the report is presented periodically. Timeliness is the time lag that occurs in the dissemination of the report. Relevance means that the report can provide the information needed by regulators, the public, and the market to make decisions effectively. Openness is the ease with which people can access information, influence, and demand government accountability for fiscal policy.

Fiscal transparency serves to create effective fiscal management. First, fiscal transparency ensures that economic policies are taken based on an accurate assessment of the current fiscal conditions, costs and benefits of policy changes, and potential risks in forecasting future fiscal conditions. In addition, with fiscal transparency, regulators, markets, and the public can obtain information for efficient financial decision-making and can demand the performance of government fiscal management. Fiscal transparency 
facilitates the monitoring of fiscal developments internationally to mitigate the spillover effect between countries. In addition, the market's credibility and trust in the government will increase. Countries with high fiscal transparency tend to have controlled debt to GDP ratios and credit default swap spread (CDS) (IMF, 2012).

\section{1) Fiscal Transparency Code}

The Fiscal Transparency Code 2014 has four pillars and three application categories (IMF, 2018). The four pillars consist of fiscal reporting; fiscal and budgeting estimates; fiscal risk analysis and management; and management of income resources. In general, the results of the assessment classify the application into three groups. The basic practice is the minimum standard that must be achieved by IMF member countries. A good practice is the achievement of intermediate goals that require stronger institutional capacity. Advance practice is a reflection of relevant international practice and is in line with current practices and policies.

The dimensions of risk disclosure and analysis in the pillars of risk analysis and management include summary reports of macroeconomic risks, risks from specific sources, and long-term sustainability of public finances. This dimension requires the government to issue periodic brief reports on the risks to the fiscal outlook (IMF, 2018). The principles relevant to disclosure of fiscal risk in Financial Notes include the principles of macroeconomic risks and certain fiscal risks. The principle of long-term fiscal sustainability analysis is relevant for the Long-term Fiscal Sustainability Report prepared by the Fiscal Policy Agency. Fiscal Transparency indices are developed around four different clusters of practices: data assurance, medium-term budgeting, budget execution reporting, and fiscal risk disclosure (Hameed, 2005).

In the principle of macroeconomic risk, the government reports how fiscal outcomes can deviate from the baseline estimate as a result of deviating macroeconomic assumptions (IMF, 2018). The observed indicators can include GDP, inflation, unemployment, interest rates, commodity prices, and exchange rates. To reach an advanced level of practice, the government must include a sensitivity analysis, alternative scenarios, and a probabilistic estimate of fiscal performance in the budget documentation.

In the principle related to specific fiscal risks, the government provides regular summary reports on the main specific risks against the fiscal forecast. The IMF describes the scope of certain fiscal risks including the financial sector, lawsuits, state government, BUMN, government cooperation with business entities (PPP), natural disasters, and variations in the valuation of government assets and liabilities. Certain fiscal risks are divided into explicit risks and implicit risks. To achieve an advanced level of practice, the 
IMF requires the government to disclose the main specific risks in a concise report along with an estimate of their magnitude and likelihood if they can be predicted. Fiscal risks were classified into general macroeconomic or specific risks (Budina \& Petrie, 2013). Table 1 summarizes the criteria for achieving the application categories for the principles of specific macroeconomic risk and fiscal risk.

Table 1. Achievement Criteria for Application Categories for Specific Macroeconomic and Fiscal Risk Principles

\begin{tabular}{lll}
\hline \multicolumn{1}{c}{ Level } & \multicolumn{1}{c}{ Macroeconomic Risk } & \multicolumn{1}{c}{ Specific Fiscal Risk } \\
\hline Basic practice & $\begin{array}{l}\text { The government engages a } \\
\text { discussion of the sensitivity of } \\
\text { fiscal outcomes against key } \\
\text { macroeconomic assumptions. }\end{array}$ & $\begin{array}{l}\text { The government discloses the } \\
\text { main specific risks in a } \\
\text { qualitative summary report. }\end{array}$ \\
\hline Good practice & $\begin{array}{l}\text { The government engages a } \\
\text { sensitivity analysis of fiscal } \\
\text { outcomes along with } \\
\text { macroeconomic scenarios and } \\
\text { fiscal forecasts. }\end{array}$ & $\begin{array}{l}\text { The government discloses the } \\
\text { main specific risks in a summary } \\
\text { report and their magnitude. }\end{array}$ \\
\hline $\begin{array}{l}\text { Advanced } \\
\text { practice }\end{array}$ & $\begin{array}{l}\text { Sensitivity analyzes, alternative } \\
\text { scenarios, and probabilistic } \\
\text { estimates of fiscal outcomes in } \\
\text { budget documentation. }\end{array}$ & $\begin{array}{l}\text { The government discloses the } \\
\text { main specific risks in a summary } \\
\text { report along with an estimate of } \\
\text { their magnitude and likelihood } \\
\text { where they can be predicted. }\end{array}$ \\
\hline
\end{tabular}

Source: IMF (2018)

\section{2) Public Expenditure and Financial Accountability}

One of the alternative fiscal transparency assessments besides the Fiscal Transparency Code is Public Expenditure and Financial Accountability (PEFA). PEFA provides a framework for assessing and reporting on the strength of the public sector financial management in a country (PEFA, 2016). The goal of good public sector financial management is to ensure government policies are implemented according to plan and achieve goals (PEFA, 2016). The PEFA framework identifies seven pillars of the public sector financial management performance, including budget reliability, transparency of public finances, management of assets and liabilities, policy-based fiscal strategy and budgeting, predictability and control in budget execution, accounting and reporting, and external scrutiny, and audit. Disclosure of fiscal risk is included in the pillar of management of assets and liabilities.

In the pillar of management of assets and liabilities, PEFA defines expectations, indicators, and dimensions of measured performance. In this pillar, assessment is useful for ensuring that: public investment provides value for money, as well as ensuring that the government records and manages assets, identify fiscal risks, and manages debt and collateral prudently in the planning, approval, and monitoring processes. To assess the 
fulfillment of these expectations, the assessment in these pillars uses four indicators, namely: fiscal risk reporting, public investment management, public asset management, and debt management. The fiscal risk reporting indicator generally measures how far the fiscal risk of the central government is disclosed.

The fiscal risk reporting indicator has three evaluation dimensions, namely: monitoring of public corporations, monitoring of subnational governments, and contingent liabilities and other fiscal risks (PEFA, 2016). The monitoring dimension of public corporations evaluates to what extent information related to the financial performance of business entities controlled by the central government is available in audited financial reports. This dimension evaluates the extent to which the government publishes consolidated annual reports on the financial performance of business entities controlled by the central government. The government can obtain the highest score in this dimension if it publishes an audited annual financial report for all business entities controlled by the central government along with a consolidated financial performance report for a period of six months after the end of the fiscal year.

The monitoring dimension of subnational governments basically evaluates the extent to which information on financial performance, including potential fiscal risk exposures from the central government, is available in the audited financial reports of local governments. To obtain a maximum score in this dimension, the government needs to publish annual financial reports of all regional governments along with annual consolidated local government financial performance reports no later than nine months after the end of the fiscal year.

The contingent liabilities and other fiscal risks dimension is a dimension that evaluates the monitoring and reporting of explicit contingent liabilities from central government programs and activities, including those that are outside the budget. The government gets the maximum score if the government publishes an annual report that quantifies and consolidates all information on significant contingent liabilities and other fiscal risks to the central government.

\section{Method}

This research uses a qualitative descriptive method through case studies. Case studies are the right strategy for finding answers to questions about how or why, where the control of phenomena that is owned by researchers is very limited and focuses on contemporary or current phenomena (Yin, 2014). Case studies can also be used to develop an in-depth analysis of a case, in the form of a program, event, activity, or process. Cases are limited by 
time and activity and complete information is collected using various data collection procedures based on a predetermined time (Creswell, 2014).

The data used are secondary data in the form of documents, notes, articles, business processes, work procedures, and regulations regarding risk management and fiscal risk management and disclosure in the APBN by the fiscal risk management unit at the Ministry of Finance. The main principle of qualitative data analysis is to process and analyze the collected data into systematic, orderly, structured, and meaningful data so that it can be used to answer the problems formulated in the research. The data analysis process consists of data reduction, data presentation, and drawing conclusions (Miles \& Huberman, 1984). In this study, data analysis was carried out by deepening the understanding of the data and interpreting the results of the data analysis. The steps taken to analyze the data are describing the data, conceptualizing the data, and then drawing a conclusion from the results of the data analysis.

\section{Discussion}

The implementation of Risk Management in the Ministry of Finance is mandated by laws and regulations. Article 58 of Law No.1 of 2004 states that the internal control system aims to improve performance, transparency, and accountability in the management of state finances. Furthermore, the regulation mandates the establishment of government regulations to set the internal control system. The regulation is Government Regulation Number 60 of 2008 concerning Government Internal Control Systems. This government regulation is the basis for the preparation of technical regulations in each ministries/agency.

\section{Fiscal Risk Management Process by the Fiscal Risk Management Unit}

The definition of fiscal risk established by the government has undergone developments in the Financial Note. The government publishes the definition of fiscal risk for the first time in the Financial Note for Fiscal Year 2012 as a potential additional APBN deficit caused by something beyond the government's control. Furthermore, in the Financial Note for Fiscal Year 2013, the government added aspects of fiscal pressure on the financing side in the definition of fiscal risk. Recently, in the Financial Note for Fiscal Year 2020, the government added contingent liabilities as an off-the-balance sheet aspect to the definition of fiscal risk. Even though it has only been added to the definition of fiscal risk, the government has disclosed contingent liabilities since the Fiscal Note for Fiscal Year 2008. In full, the government defines fiscal risk in the Fiscal Note for Fiscal Year 2020 as anything that in the future can create fiscal pressure on the APBN, either originating from the side of state 
revenue, state expenditure, budget financing, and contingent fiscal risks.

To date, there is no regulation or public document in Indonesia that defines state financial risk. In 2019, the Ministry of Finance's fiscal risk management unit, in this case, the Directorate of State Financial Risk Management (PRKN), Directorate General of Financing and Risk Management, is trying to formulate a definition of state financial risk by deriving it from the definition of risk and state finance. The fiscal risk management unit divides the definition of state financial risk into two terms. In the short term, state financial risk is the possibility of a difference between the worse realized condition in the current year (fiscal deficit) and the conditions predicted during the planning of state financial management. In the long term, the risk of state finance constitutes a policy and economic condition that drives the deterioration of state finances, as indicated by the negative primary balance parameter in the long term.

Fiscal risk is defined as part of the country's financial risk. Fiscal risk management is the short-term management of state financial risk with the scope of risk sources as disclosed in the Financial Note. State financial risk management includes medium and long-term efforts. Medium-term risk management takes into account the primary balance, the ratio of debt to gross domestic product (GDP), economic growth, interest rates, inflation rates, current accounts, and includes contingent liabilities. Risk management includes long-term risk categories with sensitivity analysis. Figure 3 illustrates the context for managing state financial risk.

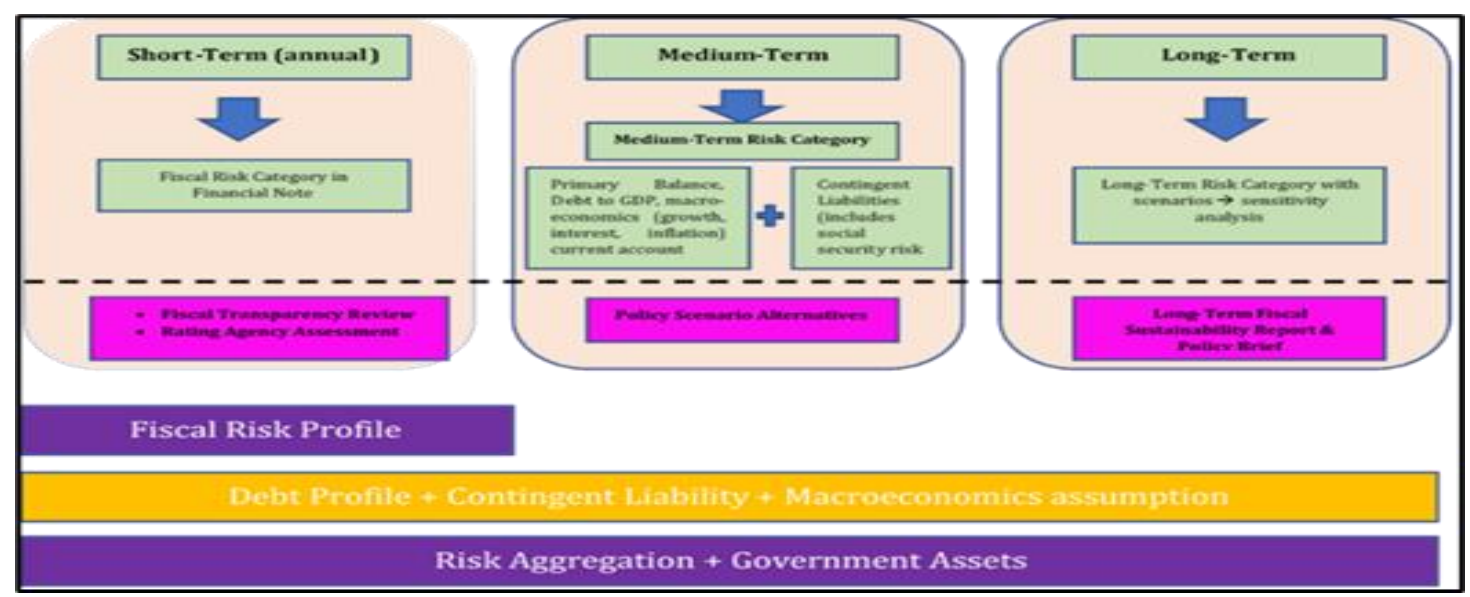

Source: Ministry of Finance

Figure 3. Formulation of State Financial Risk Management Context

\section{1) Procedures and Framework for State Financial Risk Management}

Implementation of fiscal risk management pushes the fiscal risk management unit to apply standard operating procedures regarding the Formulation of Recommendations for State Financial Risk Management. In general, the process includes four stages of activity, such as collecting data and materials for risk identification, analyzing and formulating draft 
recommendations, reviewing recommendations, and approving draft recommendations so that they can be followed up with risk mitigation actions by risk owners. The stages of this activity are the result of the adaptation of the risk management stages as stated in ISO 31000: 2009.

Even though there are standard operating procedures, the fiscal unit does not have a written framework. Fiscal risk management unit requires a framework as a guide that provides definitions and concepts related to the management of state financial risks, the scope, coverage of sources of state financial risk, as well as the risk management process flow including identification, analysis, evaluation, mitigation, monitoring and communication, and reporting. The framework is useful in building uniformity of understanding and placing the roles of stakeholders in risk management so that the continuity of the process after the formulation of risk mitigation is guaranteed.

\section{2) Fiscal Risk Management Process}

Figure 4 illustrates the process of managing state financial risk including fiscal risk. Regarding the risk sources, the fiscal risk management unit determines the risk management context and collects relevant data to further carry out the risk identification process. Furthermore, the fiscal risk management unit carries out a risk analysis to determine the impact level and the likely risk level. To assess risk, the results of risk analysis are mapped into a risk analysis matrix (risk map). The risk assessment results form the basis for the fiscal risk management unit to develop risk mitigation alternatives. The fiscal risk management unit provides analysis results and risk mitigation recommendations to the Minister of Finance and/or related parties to be followed up with risk mitigation implementation. Furthermore, the fiscal risk management unit carries out monitoring and evaluation of risks and the implementation of mitigation. The fiscal risk management unit documents all risk analysis results and recommendations in the risk register which is currently under development.

The fiscal risk management unit uses several models to assist fiscal risk analysis. In analyzing the risk of changes in basic macroeconomic assumptions, the fiscal risk management unit uses the Fiscal Risk Reserve Fund Model. The model calculates the need for funds as a result of changes in basic macroeconomic assumptions. The fiscal risk management unit has a Macro Stress Test Model to measure changes in state revenues from SOEs as a result of changes in macroeconomic variables. 


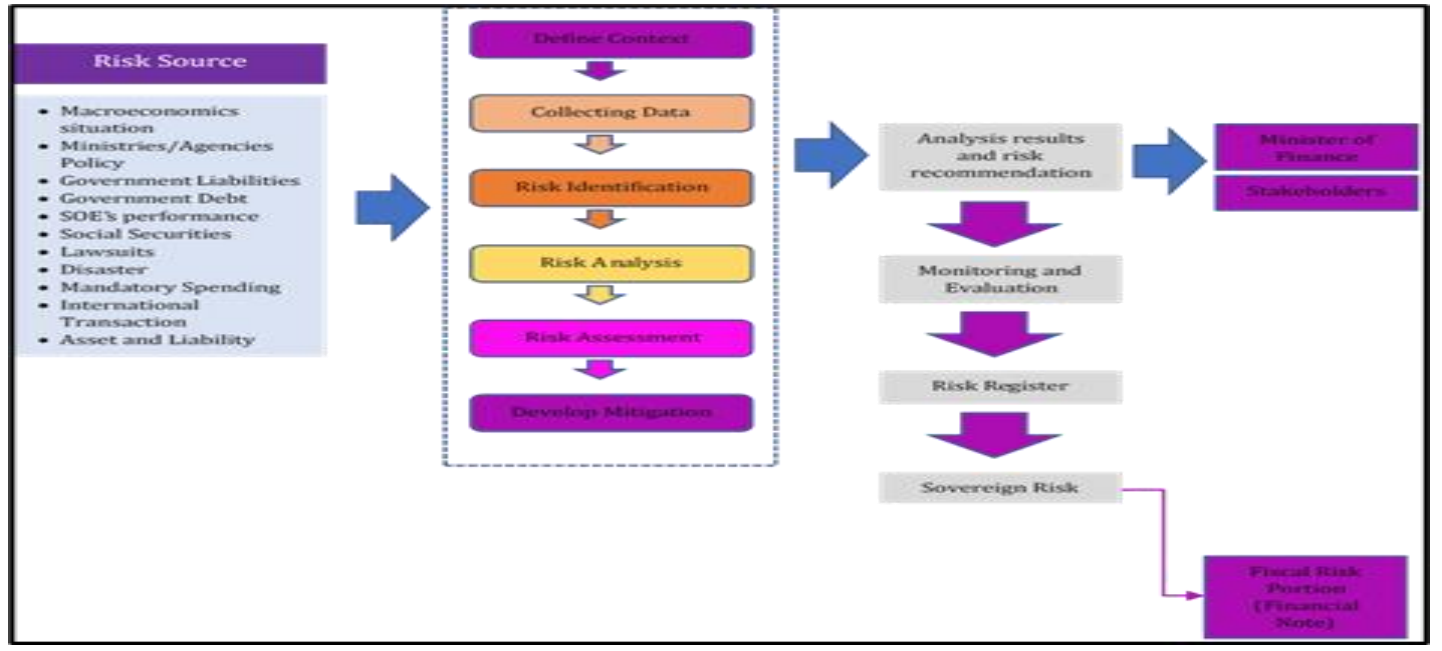

Source: Ministry of Finance

Figure 4. State Financial Risk Management Process

The fiscal risk management unit has formulated a risk analysis matrix to describe the position of risk sources in a consolidated manner. The risk analysis matrix is a combination of the level of impact and the level of risk possibility. Impact levels are grouped based on the nominal value of the impact on GDP. Meanwhile, the probability level is a grouping based on the percentage of the chance of a risk occurring. The risk magnitude is a combination of the level of impact and the level of risk. With a risk analysis matrix, the fiscal risk management unit classifies the risk magnitude into five levels from the safest magnitude to the dangerous one, including dark green, light green, yellow, orange, and red. Figure 5 illustrates the classification of the impact level and the level of risk possibility along with the risk analysis matrix.

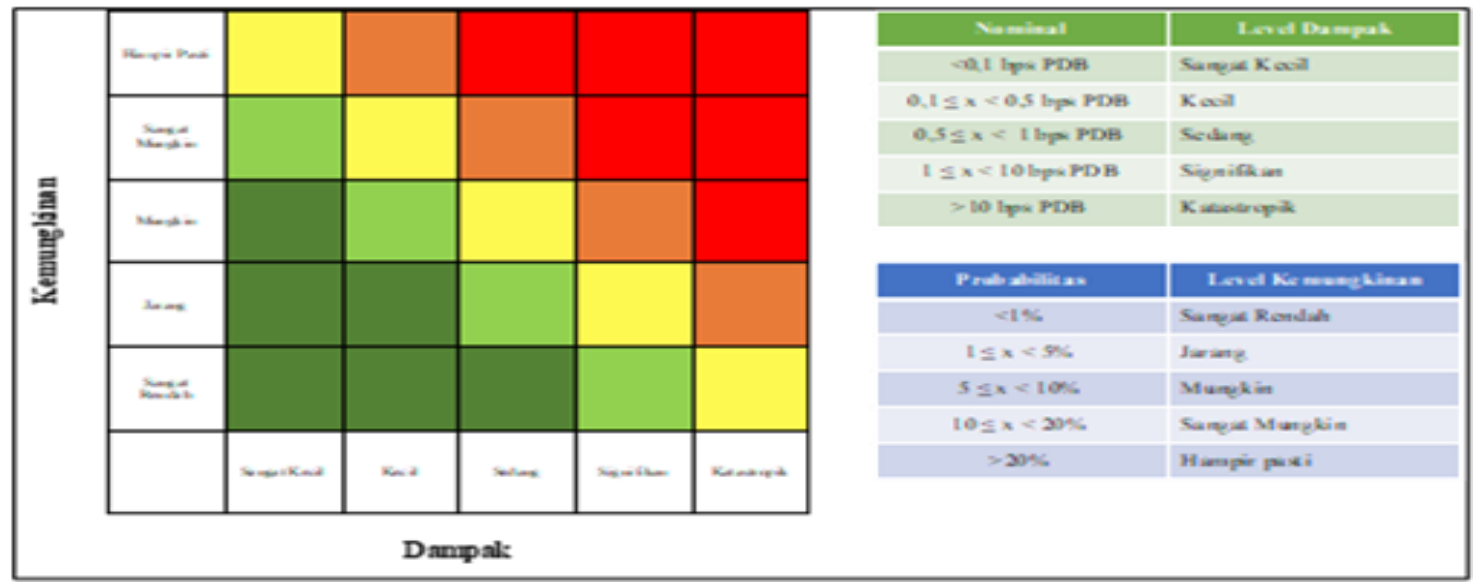

Source: Ministry of Finance

Figure 5. Classification of Impact Levels and Risk Possibility along with the Risk Analysis Matrix

3) Fiscal Risk Disclosure in the Financial Note for Fiscal Year 2020

Since 2008, the scope of sources of fiscal risk in the Financial Notes has developed. In the 2020 Fiscal Year, the government simplifies the classification of sources of fiscal risk 
into three groups. (1) risk of changes in economic conditions by presenting: analysis of APBN sensitivity to changes in basic macroeconomic assumptions, the sensitivity of medium-term APBN projections to changes in basic macroeconomic assumptions, and SOE fiscal risk sensitivity to changes in basic macroeconomic assumptions; (2) APBN risk includes income risk, expenditure risk, central government debt risk, and contingent liabilities; and (3) certain fiscal risks include disaster risk, lawsuits against the government, risk of housing finance programs for low-income people, risk of developing new and renewable energy, and risk of assigning SOEs. Disclosure of the sources of fiscal risk has strategic objectives, including increasing stakeholder awareness in managing fiscal policy; increase fiscal transparency; increasing fiscal accountability; as well as creating fiscal sustainability.

Starting from Fiscal Year 2020, the government presents a risk analysis matrix (risk map). With this risk analysis matrix, readers can see the position of the sources of fiscal risk as a whole. The risk analysis matrix at the beginning of the Fiscal Risk chapter presents the initial risk position of all risks. The government presents the expected risk shift after mitigation to explain each source of fiscal risk. Therefore, the reader is not yet able to see the expected position of the post-mitigation fiscal risk sources in a consolidated manner. Figure 6 constructs the fiscal risk position before fiscal risk mitigation and the expected post-mitigation fiscal risk position. In addition, the risk analysis matrix in the Financial Notes does not yet classify the magnitude of risk which is generally presented with a color code. In addition, the matrix does not yet present a risk tolerance line as the boundary for the risk appetite area.

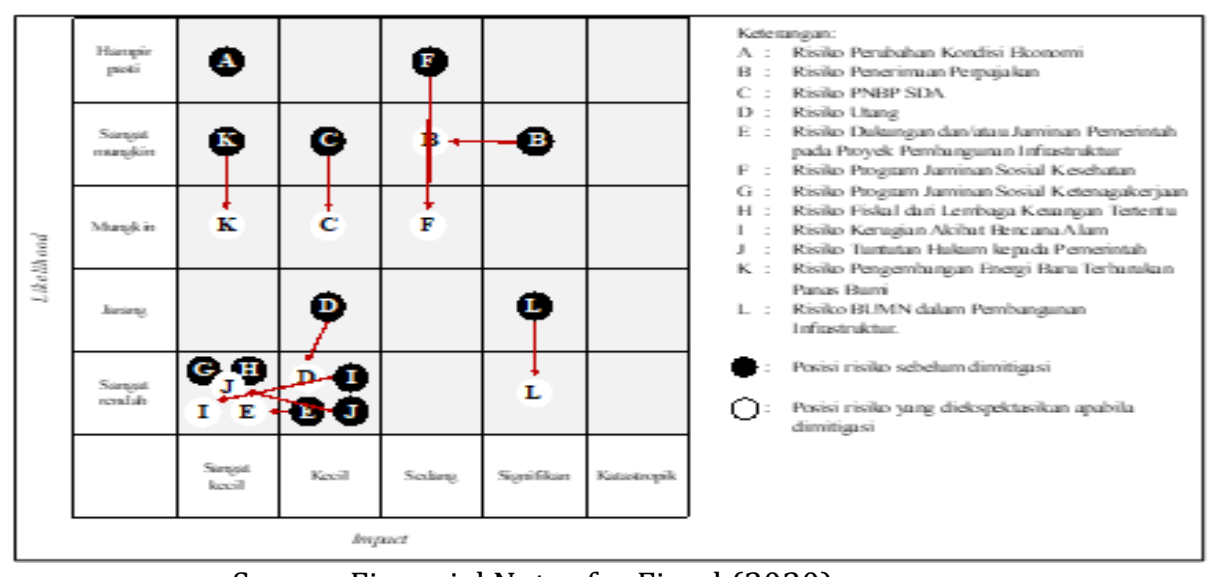

Source: Financial Notes for Fiscal (2020)

Figure 6. Risk Analysis Matrix in Financial Notes for Fiscal Year 2020 


\section{Risk Management in the Fiscal Risk Management Process}

The existence of a risk management system can emerge a culture of awareness of the various risks posed by the Risk Owner Unit, including fiscal risks. The regulations regarding the application of risk management have mandated that the leadership is committed to considering risks in organizational decision-making. In addition, the existing system has promoted two-way communication between the Risk Owner Unit levels including risk reduction and/or escalation as long as it is relevant to the unit's duties and functions as well as risk management capabilities. Normalization of work unit risk management as part of the organization's business processes strengthens the fulfillment of the principles of integration (ISO, 2018).

The risk management system guarantees a check and balance mechanism to maintain the quality of the risk management process and to obtain the best available information for risk management. The existing structure has adopted the three lines of defense principle by separating the implementation function at the Risk Owner Unit, review of compliance at the Risk Management Compliance Unit, as well as auditing and maturity assessment at the Internal Auditor (IA). The clear distribution of roles among the three units in the regulation increases the IA's focus on the compliance function. The establishment of the Risk Management Compliance Unit will force IA and Risk Owner Unit to comply with the regulation. With the regulation of the risk management structure as referred to in these regulations, there is an independent party to the implementation of the risk management process that ensures the quality of the work unit's risk management as well as the quality of data and information used and generated from the risk management process.

Risk management at the Ministry of Finance includes establishment and uniformity of risk management concepts; detailed process guides, and operating an early warning system on risk status through the main risk indicator. This decision establishes the definitions, concepts, and criteria in risk management that will be carried out by the risk management structure. It is still necessary to establish definitions and concepts in risk management to simplify terms and understandings and adapt the risk management process to the needs. Uniformity is useful to ensure consistency of information and the output of the risk management process.

Even though the components of the activity comply with these standards, the existing rules modify the flow to match the feedback from implementing the risk management process. A detailed process guide serves as a guide for the Risk Owner Unit to find out the activities that need to be carried out in risk management. This decision encourages the use of the main risk indicators as a monitoring system and early detection of changes in risk 
status. The availability of an early detection system supports the acceleration of the treatment process to keep risks within the area of risk appetite. The three scopes of governance arrangements realize the fulfillment of risk management that is integrated, structured and comprehensive, inclusive, and according to the needs of the organization.

There is an intersection of the scope of risk sources that are managed through the work unit's risk management system with fiscal risk management as part of the management of state financial risk. State financial risk with the work unit in the Ministry of Finance as the risk owner is covered by the work unit's risk management system and includes the scope for state financial risk. State financial risks that do not intersect with the work unit's risk management system originate from public entities outside the Ministry of Finance including quasi-government institutions such as SOE, Central Banks, and other public entities. Fiscal risk as part of the country's financial risk covered by the two systems also has a slice. There is a fiscal risk with the risk owner, namely the internal Ministry of Finance which is included in the system according to the decision and includes sources of fiscal risk that are managed by the fiscal risk management unit. Fiscal risks that do not intersect are fiscal risks that originate from public entities outside the Ministry of Finance, including quasi-government. Thus, the scope of fiscal risk and state financial risk is broader than the scope of the work unit's risk management system.

Although there is an intersection of managed risk coverage, the unit's risk management system and fiscal risk management are separate and do not have a direct process linkage. An indication of the absence of integration of the two systems is the difference in objectives between the two systems. First, the unit's risk management objectives refer to organizational risks and tend to the aspects of achievement and added value of the organization's goals as well as aspects of compliance. Fiscal risk management has a direct objective of managing state finances to maintain fiscal sustainability. These differences in objectives affect the scope of risk-managed by the two systems so that the unit's risk management system includes reputation, fraud, compliance, and operational risks as a representation of risk that is closely related to the organization.

The scope of fiscal risk as shown in Figure 7 above is broader than the scope of the fiscal risk category in the unit's risk management system which is limited to the fiscal risk inherent in the unit's strategic map. In addition to managing fiscal risk that comes from within the Ministry of Finance, the fiscal risk management unit also analyzes and coordinates fiscal risk mitigation efforts that arise and are owned by entities outside the Ministry of Finance. Thus, the scope of this fiscal risk source is broader than the scope of the fiscal risk category in the unit's risk management system. 


\section{$S$}

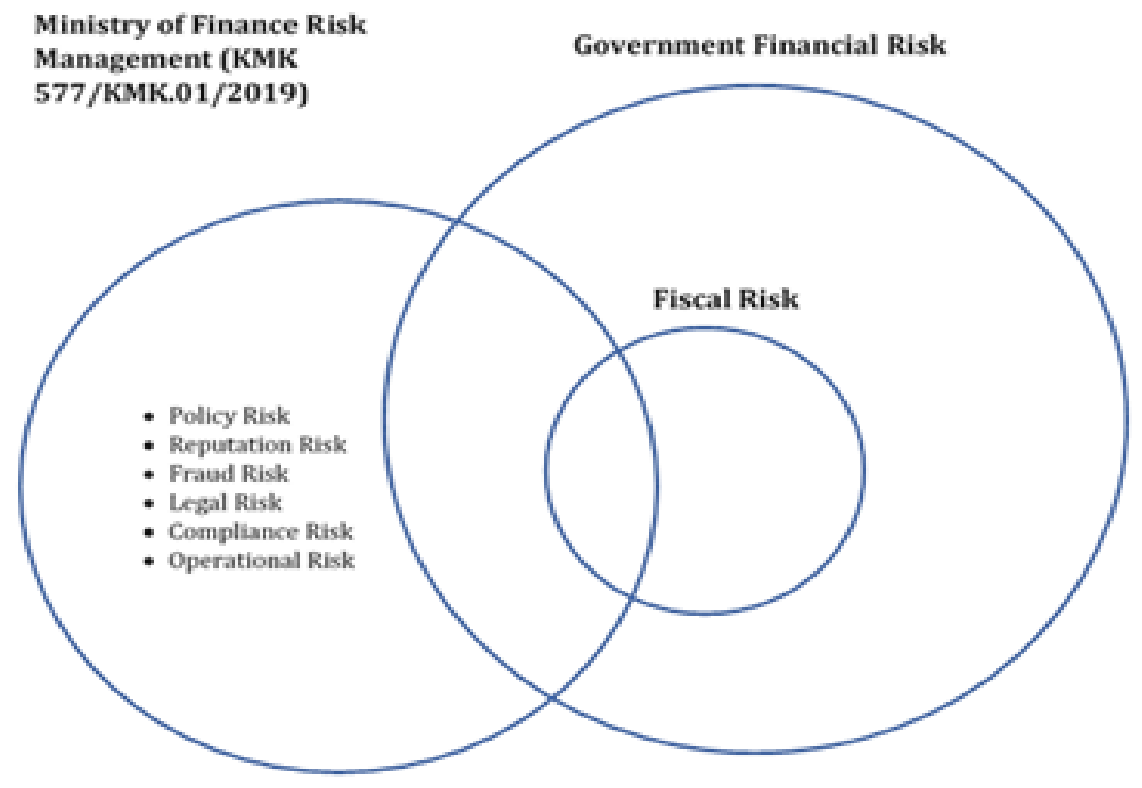

Source:Ministry of Finance

Figure 7. Intersection of Risk Coverage in the Risk Management Framework of Risk Owner and State Financial Risk

Another indication that the unit's risk management system has not been integrated is the inconsistency in the context for state financial risk, including fiscal risk between the two systems. This non-uniformity of context includes the definition of country financial risk as well as the impact and likelihood criteria used in risk mapping. In 2019, the fiscal risk management unit proposed a definition of state financial risk as a policy and economic condition that led to a deterioration in state finances as indicated by a negative primary balance parameter in the long term. On the other hand, the unit's risk manager in the ministry defines the risk category of state finance and state assets as risks related to the fiscal condition of the central government which includes the macroeconomic framework, budgeting, taxation, customs, treasury, and related to state assets which include stateowned assets, restricted state assets, government investment, and other state assets. Another difference that was observed was the range of possible risk classifications and the definition of different country financial risk impact ratings. This difference causes the results of the risk assessment by the work unit to potentially differ from the results of the risk analysis for the same scope of risk. The unsynchronized risk assessment has an impact on the effectiveness of planning, implementing mitigation, and coordinating fiscal risk management. 
The integration of the unit's risk management implementation with the fiscal risk management process can improve the integration and optimization of the monitoring and evaluation process. This has been achieved because the integration of the two business processes enables the implementation of comprehensive and non-partial monitoring and evaluation by the Risk Owner Unit at the Ministry of Finance and the fiscal risk management unit. Utilization of the system can be used to assist in monitoring the implementation of risk mitigation in order to ensure compliance and the best efforts that can be made by the Risk Owner Unit which has a state financial risk category so that risk status is improved to a safe level and according to the expectations of all stakeholders in fiscal risk management. Utilization of the system can be used to assist in monitoring the implementation of risk mitigation in order to ensure compliance and the best efforts that can be made by the Risk Owner Unit which has a state financial risk category so that risk status is improved to a safe level and according to the expectations of all stakeholders in fiscal risk management.

\section{Conclusion}

The Risk Management Framework in the Ministry of Finance has been regulated through a Ministerial Decree. It is able to provide several benefits, such as institutionalizing the norm for developing a risk awareness culture through leadership commitment, two-way communication, and the attachment of risk management to business processes; creating a check and balance mechanism by implementing three lines of defense to maintain the quality of risk management and ensure the best available information for risk management; regulating fiscal risk management governance in detail which includes uniformity of concepts, activity implementation guidelines, and utilization of key risk indicators as an early warning system; encouraging the implementation of risk management process documentation through the governance of the preparation and submission of risk monitoring reports. To support fiscal risk management, the government has formed a unit to implement analysis, formulation of recommendations, and coordination of fiscal risk management. The problem that occurs is that there is still a gap in fiscal risk management. These gaps include ideal risk coverage, availability of a written framework as a basis for managing state financial risk including fiscal risk, risk management processes that are not yet integrated, and the absence of a periodic and holistic reporting mechanism for managing state financial risk.

In order to overcome the gap, it is necessary to formulate a written framework as a fiscal risk management basis. The formulation of a framework has the urgency of setting up clear risk selection procedures within the framework of cost-efficiency fiscal risk mitigation. 
This framework also has urgency in legal and administrative aspects to allocate tasks and responsibilities among stakeholders including risk owners and managers. The framework needs to cover three dimensions, macroeconomic context; certain fiscal risks; and institutions that act as triggers for owners and managers of fiscal risk in managing risks.

In disclosing fiscal risk in the 2020 fiscal year, the government has used a risk map to draw the overall fiscal risk position by taking into account the level of impact and the level of risk possibility. The mapping procedure provides visual information on fiscal risk conditions before mitigation as well as expected fiscal risk conditions after the risk mitigation process is carried out. The results of the mapping will translate quantitative risk information into qualitative information that is easily understood by stakeholders. The mapping process can encourage improvement in the risk analysis process by measuring the likelihood of the risk occurring. Disclosure of the fiscal risk map can also meet the requirements for achieving an advanced level of fiscal transparency implementation because the government has disclosed the magnitude and likelihood of fiscal risk occurring in the Financial Notes.

Several aspects that require attention in order to improve the implementation of fiscal risk disclosure are the publication of the impact level criteria and the criteria for the possible level of fiscal risk as a basis for mapping the sources of fiscal risk. This criterion is useful so that stakeholders have the same perception of fiscal risk conditions. In addition, it is also necessary to present a risk map along with a heat map as a representation of risk appetite or risk tolerance level in line with the direction of fiscal policy.

\section{REFERENCES}

Baldacci, E., Gupta, S., \& Mati, A. (2011). Political and fiscal risk determinants of sovereign spreads in emerging markets. Review of Development Economics, 15(2), 251-263.

Brixi, H. P., \& Schick, A. (2002). Government at Risk: Contingent Liabilities and Fiscal Risk. Washington, DC: The International Bank for Reconstruction and Development/The World Bank.

Budina, N., \& Petrie, M. (2013). Managing and controlling fiscal risks: IMF.

Cebotari, A., Davis, J., Lusinyan, L., Mati, A., Mauro, P., Petrie, M., \& Velloso, R. (2009). Fiscal Risks: Sources, Disclosure, and Management. Washington, DC: International Monetary Fund. 
Creswell, J. W. (2014). Research Design: Qualitative, quantitative, and mixed methods approaches, 4th Ed. . California: Sage Publication.

Everaert, G., Fouad, M., Martin, E., \& Velloso, R. (2009). Disclosing Fiscal Risks in the PostCrisis World. Washington, DC: International Monetary Fund.

Gruber, J. (2019). Public finance and public policy 6th Edition. New York: Macmillan.

Hameed, F. (2005) Fiscal transparency and economic outcomes. In I. M. Fund (Series Ed.), (pp. 1-40): IMF.

IMF. (2012). Fiscal Transparency, Accountability, and Risk. Washington DC: International Monetary Fund.

IMF. (2018). Fiscal Transparency Handbook. Washington, DC: International Monetary Fund.

IMF. (2019). Financial Programming and Policies: Volume I. Washington DC: IMF Institute for Capacity Development.

ISO, I. O. f. S. (2018). Norma Internasional ISO 31000 Edisi Kedua: Manajemen Risiko Pedoman. Jakarta: Badan Standardisasi Nasional.

Lloyd-Ellis, H., \& Zhu, X. (2001). Fiscal shocks and fiscal risk management. Journal of Monetary economics, 48(2), 309-338.

Makhlani, M. (2009). OVERVIEW ATAS TRANSPARANSI FISKAL DALAM PERSPEKTIF RISIKO: SUATU KOMPARATIF DAN STUDI LITERATUR. Kajian Ekonomi dan Keuangan, 13(1), 11-31.

Miles, M. B., \& Huberman, A. M. (1984). Qualitative Data Analysis: A Sourcebook of new Methods. California: SAGE Publication Inc.

Mullai, A. (2006). Risk management system-risk assessment frameworks and techniques (Vol. 5). Turku: DaGoB Project Office.

PEFA, S. (2016). Framework for Assessing Public Financial Management. Washington DC: PEFA Secretariat.

Redja, G. E., \& McNamara, M. J. (2017). Principles of Risk Management and Insurance. 13th Edition, . Harlow: Pearson Education Limited.

Rittenberg, L., \& Martens, F. (2012). Enterprise Risk Management: Understanding and Communicating Risk Appetite. New York: Committee of Sponsoring Organizations of the Treadway Commission (COSO).

Robbins, S. P., \& Coulter, M. (2016). Management (13th global edition). Harlow.

Sidabutar, M., \& Kurniawan, M. A. (2018, December). Menimbang COSO dan ISO. Buletin Kinerja, Sekretariat Jenderal Kementerian Keuangan Edisi XXXVIII, Kuartal IV 2018, 8-9. 
Yin, R. K. (2014). Studi Kasus: Desain dan Metode (diterjemahkan oleh M. Djauzi Mudzakir). Jakarta: Rajawali Pers. 